\title{
Medical Ethics in Qișāṣ (Eye-for-an-Eye) Punishment: An Islamic View; an Examination of Acid Throwing
}

\author{
Amir Alishahi Tabriz ${ }^{1}$ Hossein Dabbagh ${ }^{2}$. \\ Harold G. Koenig ${ }^{3}$
}

Published online: 22 September 2015

(C) Springer Science+Business Media New York 2015

\begin{abstract}
Physicians in Islamic countries might be requested to participate in the Islamic legal code of qișās, in which the victim or family has the right to an eye-for-an-eye retaliation. Qișās is only used as a punishment in the case of murder or intentional physical injury. In situations such as throwing acid, the national legal system of some Islamic countries asks for assistance from physicians, because the punishment should be identical to the crime. The perpetrator could not be punished without a physician's participation, because there is no way to guarantee that the sentence would be carried out without inflicting more injury than the initial victim had suffered. By examining two cases of acid throwing, this paper discusses issues related to physicians' participation in qișās from the perspective of medical ethics and Islamic Shari'a law. From the standpoint of medical ethics, physicians' participation in qiṣāṣ is not appropriate. First, qișās is in sharp contrast to the Hippocratic Oath and other codes of medical ethics. Second, by physicians' participation in qișāṣ, medical practices are being used improperly to carry out government mandates. Third, physician participation in activities that cause intentional harm to people destroys the trust between patients and physicians and may adversely affect the patient-physician relationship more generally. From the standpoint of Shari'a, there is no consensus among Muslim scholars whether qișāṣ should be performed on every occasion. We argue that disallowing physician involvement in qișāș is necessary from the perspectives of both medical ethics and Shari'a law.
\end{abstract}

Hossein Dabbagh

hossein.dabbagh@csls.ox.ac.uk

Amir Alishahi Tabriz

amir17@live.unc.edu

Harold G. Koenig

harold.Koenig@duke.edu

1 Department of Health Policy and Management, The Gillings School of Global Public Health, University of North Carolina at Chapel Hill, 170 Rosena Hall, CB, \#7400, 135 Dauer Drive, Chapel Hill, NC 27599-7400, USA

2 Centre for Socio-Legal Studies, University of Oxford, Manor Road Building, Manor Road, Oxford OX1 3UQ, UK

3 Duke University Medical Center, Durham, NC, USA 
Keywords Medical ethics · Qiṣāṣ · Capital punishment · Islam · Acid throwing

\section{Introduction}

The Islamic law of qișās is a Shari'a-based legal code based on reciprocal justice. In traditional Islamic societies, the victim or his/her family had the right to eye-for-an-eye retaliation that remains codified in the modern Islamic legal system as qiṣass. Unlike other categories of crime in the Islamic penal code, which leaves the administration of punishment in the hands of the Islamic jurisprudent, the verdict of qișas belongs to the aggrieved. Qișass, therefore, emphasize the rights of the victim who can either pardon the condemned or impose the sentence. Qiṣas only is issued as a punishment in the case of deliberate killing (qiṣāss-from-first-order-killing) and in the case of intentional physical injury (qișāss-from-assault-and-battery). In this paper, we mainly focus on the qișaṣs-fromassault-and-battery. By examining two cases of acid throwing, we argue that physicians' participation in qișass is problematic from both a medical ethics perspective and Islamic Shari'a law, and because of the necessity of physician involvement in qișās, this practice should be abandoned for assault and battery.

\section{Two Acid Throwing Cases in Iran}

In October 2004, Majid Movahedi threw a bucket of acid in Ameneh Bahrami's face after she rejected his marriage proposal. ${ }^{1}$ Ameneh subsequently underwent seventeen surgeries but remains seriously disfigured and blind in both eyes. The Iranian judiciary sentenced Majid to be blinded by acid based on the provisions of qișạs (retaliation). After 7 years, in July 2011, Majid was taken to Tehran's judiciary hospital to be blinded with acid. However, Ameneh spared him and halted the qișass sentence at the last minute. She said she was moved to pardon her assailant because the Quran recommends mercy when demanding qișāss. Ameneh's pardon gave her family consolation and produced an inner peace within her.

The acid thrower in the case of Davood Roshanaei was not as fortunate as Majid. Davood experience severe and widespread damage to his face, ears, and eyes when his assailant threw acid on him 10 years ago (approximately the same time as Ameneh's case). He was adamant about his right of qișass. However, there was no way to guarantee that the sentence would be carried out without inflicting more injury than the victim had initially suffered. Therefore, the Iranian juridical system had no way except to alter the punishment in such a way that it would guarantee that the same injuries would be inflicted as occurred with the victim. Consequently, the Iranian juridical system decided to use the most accurate method possible for this punishment: a surgical procedure. This meant that a group of surgeons would need to carry out a surgery with aim of inflicting intentional damage to the young man who threw acid on Davood. The Iranian Medical Association announced that they would not allow the performing of such the maiming surgery because it conflicted with their code of medical ethics. This case remains open at this time.

\footnotetext{
${ }^{1}$ http://www.theguardian.com/world/2011/jul/31/iran-acid-woman-pardons-attacker.
} 


\section{Argument from a Medical Ethics Perspective}

All major medical associations unanimously condemn physician involvement in any kind of torturing, maiming, or killing people including capital punishment. Article 2.06 of the American Medical Association Code of Medical Ethic, states:

A physician, as a member of a profession dedicated to preserving life when there is hope of doing so, should not be a participant in a legally authorized execution (American Medical Association 2006).

The logic behind this policy is that the physicians' participation in capital punishment is in sharp contrast to the Hippocratic Oath and physician responsibility to "do no harm" and preserve life whenever possible. The same argument can be applicable to qiṣa ș̣ for assault and battery.

The discouragement of physician involvement in capital punishment is a rare instance where all major schools of medical ethics such as Consequentialism, Principlism, and Kantianism come to an agreement that physicians should not harm people. The physicians' participation in capital punishment involves an improper use of medical skills to carry out a government mandate. By assisting with capital punishment-or in this case qișass for assault and battery - the physician is not using his/her medical knowledge in an ethical manner. Such actions have consequences more generally for the relationship between patients and physicians and the role of medicine in a civilized society. People do not trust or distrust medicine as an institution - they trust or distrust doctors (Needleman 1985). The relationship between patient and physician must be built on trust. The physician is obligated to place patients' benefits above their own interests and above the interests of other stakeholders including the government. We believe that physicians' participation in activities that caused intentional harm to people will destroy the trust on which the doctorpatient relationship is grounded.

However, not all medical practitioners are aligned with their professional organization's value and promotion of medical ethics standards. For example, many prisoners were tortured by using medical techniques during the interrogation of detainees at Guantanamo Bay. Thousands of girls in the Middle East are mutilated by physicians annually by surgical procedures involving their genital organs. Millions of Jews were executed and tortured through the assistance of Nazi doctors during World War II. Many physicians and nurse practitioners continue to participate in executions around the world. Clinician participation in these practices was initially justified by orders from their superior or by cultural beliefs and traditions. Advocates of these procedures argue that physician aid during capital punishment spares the prisoner from avoidable agony. They maintain that the prisoner will be punished as a result of the court's decision regardless of whether a physician is involved. Consequently, some physicians believe that it is their responsibility to lessen the pain of the prisoner who is already condemned to die, and even sometimes rationalize this decision by referring to the Hippocratic Oath.

The legal system of Islamic countries such as Iran requests assistance from physicians so that in the case of qișās for assault and battery the punishment will be identical to the crime. The perpetrator cannot be punished without a physician's participation. At the same time, nobody has the power to force physicians to participate in qiṣaș. Hence, because physicians have a voluntary role in this process, they have a historic chance to change these practices. 
In the case of qiṣaș for assault and battery, physician organizations could argue that this practice violates their medical codes of ethics, and therefore make it clear that they will refuse to engage in this practice if the government requests their involvement or for cultural or religious reasons. The degree of reversibility of the maiming surgery and hard to anticipate postoperative complications are the critical issues that must be addressed prior to such procedures. In the Davood case, many questions come up. Exactly what type of surgery will be performed: enucleation surgery, cutting the optic nerve, or damaging the retina? Who is responsible for postoperation complications? Does the perpetrator have the right to ask for reconstructive surgery immediately after the maiming surgery? If the perpetrator has no right to ask for reconstructive surgery, and damages supposed to be irreversible, then what happens if after sometimes Davood with the help of new technologies can regain his vision? These are questions that are difficult to answer.

\section{Argument from Shari'a Law: Playing God}

Some Muslim scholars believe that human enhancement, i.e., the use of science and technology for changing the human body is against what Islam teaches (Athar 2008; Sachedina 2009). ${ }^{2}$ They believe that such practices interfere with God's authority. There are also several philosophers such as Sandel (2007), Habermas (2003), Dworkin (2002), and Cohen (2011) who believe that we should deal with the idea of human enhancement by addressing questions about the moral status of nature. Michael Sandel, for example, writes:

In order to grapple with the ethics of enhancement, we need to confront questions largely lost from view-questions about the moral status of nature, and the proper stance of human beings toward the given world. Since these questions to verge on theology, modern philosophers, and political theorists tend to shrink from them. $(2007,9){ }^{3}$

Most of these philosophers believe that using human enhancement is not morally permissible because by doing so we can be accused of "playing God." For example, genetic engineering can help us create smarter and stronger children. Playing God is forbidden in Islam and other monotheistic religions. These philosophers and scholars find the idea of human enhancement terrifying, and that "Playing God" is a "dangerous cliché" (Coady 2009). ${ }^{4}$

However, if it is true that using human enhancement is against God's authority, why using human detraction (anti-enhancement) is not against God's authority? That is, if using modern technology to enhance one's future is against God's authority, why using modern technology to do qiṣasṣ-from-assault-and-battery and detract one's future is not against God's authority? For instance, in the case of acid throwing, a physician needs to use some modern technology to remove some parts of the perpetrator. If so, attaining qișās-fromassault-and-battery is against God's authority and could be inconsistent with God's authority. This leads us to conclude that attaining qișāṣ especially in the case of assault and battery is in fact playing God in this world. Qiṣāṣ-from-assault-and-battery is a form of

\footnotetext{
2 Quran (4:119).

3 For more details on Sandel's argument and its criticisms, see Kahane (2011, 2013).

${ }^{4}$ http://www.prospectmagazine.co.uk/blog/playing-god-is-a-meaningless-dangerous-cliche/\#. UhYYSpJOS 8A and http://blog.practicalethics.ox.ac.uk/2010/05/is-playing-god-just-a-meaningless-phrase/
} 
"playing God" in the sense that by doing qișass we are in fact playing as God, i.e., taking the role of God. However, the idea of playing God can be a severe challenge for the religious perspective. Here is why.

Believers (Muslims) think that there are certain things in this world of human beings which are God's right, not ours. Consequently, God does make a decision about them and we are not entitled to take care of them. In fact, the theological concept of "providence" works here to explain why these theistic believers endorse such claim. All theistic religions (including Islam), on one interpretation, advise their followers that one of these certain things that God has right to take care of, among other things, is the control of the creation. Unlike philosophers who thought that God is a "retired architecture," theistic religions believe that God did not only make the world. Rather, like Isaac Newton who thought that we need God to have a persistent account of time and space, believers think that God protects, cares, guides, and preserves the world all the time. For example, in Islam, Quran emphasizes that God cannot become tired and every day He is working for His plan: "And indeed We already created the heavens and the earth and whatever is between them in 6 days, and in no way has any fatigue touched Us" (50:38). ${ }^{5}$

Nevertheless, there might be an objection that how can participate in qiṣās is against God's authority when God generally prescribes the idea of qișāss, in the Holy text. It seems that it is not against God's authority.

There are several verses in Quran talking about qișās in both senses of qiṣa $\bar{s}$-from-firstorder-killing and qiṣa ạs-from-assault-and-battery. For example, we read in the Quran:

And We ordained for them therein a life for a life, an eye for an eye, a nose for a nose, an ear for an ear, a tooth for a tooth, and for wounds is legal retribution. But whoever gives [up his right as] charity, it is an expiation for him. And whoever does not judge by what Allah has revealed-then it is those who are the wrongdoers $(5: 45){ }^{6}$

However, these types of verses should be rationally and expertly interpreted. Interpretations of such controversial verses provide us a reason to either believe the content as it is or make some amendments to be acceptable.

Muslim scholars and Ulamā, especially in the Shīa School, believe that we can suspend

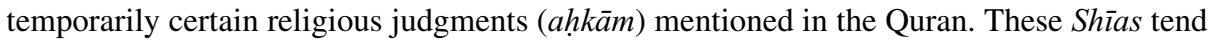
to believe that in the absence of the Innocent Imam some rituals are not obligated. As an example, most Shias tend to believe that the Friday prayer, in the absence of the Innocent Imam, is not necessary. They do not practice the Friday prayer even though it is explicitly said in the Quran. ${ }^{7}$ Among these Muslim Shīas, there are also some who believe that qișass, in both senses, can be suspended. They believe that for participating in qiṣass we need the Twelfth Innocent Imam's judgment $(\mathrm{hukm})$, but since he is not present at the moment we should suspend our judgment about qiṣās until he appears again (Khansary 1405/1985). ${ }^{8}$

Moreover, Muslim intellectuals make a distinction between two types of punishment derived from political philosophy and philosophy of law: "punishment based on deterrence" and "punishment based on desert" (Soroush 2009, 2002). These scholars believe

\footnotetext{
5 See also Quran (2:255) and (55:29).

${ }^{6}$ See also Quran (2:178-179).

7 Quran (62:9).

${ }^{8}$ One can object that Sunni Muslims will not accept this argument as it is not applicable to them. Although this can be true, we do not intend to discuss the tension between these two schools in here. All we want to do is making a room for an interpretation according to which some Quranic judgments can be suspended.
} 
that the idea of punishment (including qișass), as it is in the Quran, is more based on deterrence rather than desert. ${ }^{9}$ This entails that qiṣaș should be participated in the public so as to prevent others from doing the same crime. If so, one might raise the doubt that although attaining qișass had preventive effects in the past, there is no reason to believe that qișăs has the same preventive effect in the modern society. These Muslim intellectuals even believe that attaining qiṣa $\bar{s}$ might resemble of torturing in the modern society. Furthermore, we do not have any statistics showing that doing any sorts of qișās leads our societies to a better society with lesser crimes.

There is also another concern raised by these new Muslim scholars according to which by participating in qișaș-from-assault-and-battery, in large scale, we will have more paralyzed and disable people in our societies. Certainly, societies with more incapable people have more difficulties for the government to take care of them. So, it is not reasonable to pursue such activity.

Finally, as it is said in the Shari'a law, for attaining any kinds of qișās people who are responsible, e.g., "legal guardian" or "avenger of blood" must perform the qiṣass, not the government. In modern societies in which the idea of "nation-state distinction" becomes a necessary element for governing, attaining qiṣaș can be very problematic. Because, on the one hand, government cannot do the qișas and it is avenger of blood's responsibility to do that. On the other hand, government cannot allow individuals to participate in qiṣās privately as this makes societies unsafe and lawless. This leads us to think that we should consider the idea of qiṣaș as a historical concept which might have some place in the past but it has no place in our time.

\section{Conclusion}

Physician participation in qiṣaṣs-from-assault-and-battery is neither acceptable from a medical ethics perspective nor from the perspective of many Shari'a law scholars. Physician participation in qișăș-from-assault-and-battery is against the Hippocratic Oath and the ethical codes of many medical organizations. There is no justification for mutilating a human body in the name of revenge or justice. In Shari'a law there is no consensus among Ulamā on whether qișas should be administered on every occasion. In fact, there are some Muslim scholars who believe that suspending qișās is permissible in our time because by performing qișaș-from-assault-and-battery we are actually taking on the authority of God in this world, which is explicitly against the core principles of Islam.

Eventually, it may be physicians themselves who have the final say as to whether or not government-mandated qiṣaș continue in contemporary society. We believe that the medical community has an obligation to oppose rules and regulations that are ethically wrong. Physicians will be called on to make a choice in the cases like the ones described in this essay and we hope they will choose responsibly and ethically.

\footnotetext{
9 Quran (24:2).
} 


\section{References}

American Medical Association. (2006). Ethical Opinion E-2.06: Capital punishment. In Code of Medical Ethics of the American Medical Association (2006-2007 ed., pp. 19-20). Chicago, IL: American Medical Association.

Athar, S. (2008). Enhancement technologies and the person: An Islamic view. The Journal of Law, Medicine \& Ethics, 36(1), 59-64.

Coady, C. A. J. (2009). Playing God. In J. Savulescu \& N. Bostrom (Eds.), Human enhancement. New York: Oxford University Press.

Cohen, G. A. (2011). Rescuing conservatism. In Wallace \& Kumar (Eds.), Reasons and recognition: Essays on the philosophy of T.M. Scanlon. Oxford: Oxford University Press.

Dworkin, R. (2002). Playing god. In Sovereign Virtue. Cambridge, MA: Harvard University Press.

Habermas, J. (2003). The future of human nature. Cambridge: Polity Press.

Kahane, G. (2011). Mastery without Mystery: Why there is no Promethean Sin in Enhancement. Journal of Applied Philosophy, 28(4), 355-368.

Kahane, G. (2013). Designing children and respect for the given. In Proceedings of the 2012 UehiroCarnegie-Oxford Ethics Conference, University of Oxford.

Khansary, S. A. (1405/1985). Jame'-al-madarek fi Sharhe Mokhtasar-al-nafe'. Sadough library, Tehran: Vol. VII, Book on Qișāṣ, p. 183.

Needleman, J. (1985). The way of the physician (p. 68). Newyork: Harper \& Row Publisher.

Sachedina, A. (2009). Islamic biomedical ethics. Oxford: Oxford University Press.

Sandel, M. (2007). The case against perfection. Cambridge, MA: Harvard University Press.

Soroush, A. (2002). Reason, freedom, and democracy in Islam. Oxford University Press, Chaps. 2,7 \& 12.

Soroush, A. (2009). The expansion of prophetic experience: Essays on historicity, contingency and plurality in religion. Leiden, Boston: Brill, Chaps. 4 \& 12. 